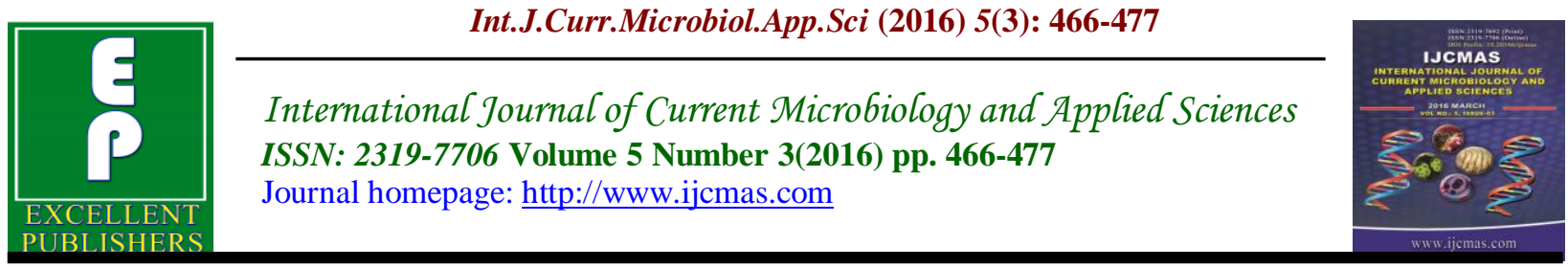

Original Research Article

http://dx.doi.org/10.20546/ijcmas.2016.503.055

\title{
Population Dynamics and Seasonal Variation of Bacterial System Utilizing Single Carbon from River Cooum and River Adyar, Chennai, Tamilnadu, India
}

\author{
Jayashree Shanmugam $^{1}$, Vadivukkarasi Ponnusamy ${ }^{1}$, \\ Mayakkannan Gopal ${ }^{2}$ and Sundaram Seshadri ${ }^{1}$ \\ ${ }^{1}$ Biomass \& Energy, Shri Murugappa Chettiar Research Centre, Chennai, India \\ ${ }^{2} \mathrm{CAS}$ in Botany, University of Madras, Chennai, India \\ *Corresponding author
}

\begin{abstract}
A B S T R A C T
Keywords

Methylotrophs,

River Adyar,

River Cooum,

India,

Enumeration.

Article Info

Accepted:

18 February 2016

Available Online:

10 March 2016

Though the single carbon utilizing bacterial system, Methylotrophs are rich source of biological compounds and good source of bio-remeidation, their diversity in river system have not paid much attention. In this study, the population of methylotrophs in two main water ways, river Coovum and river Adyar of Chennai, fourth cosmopolitan city, of India was carried out. The samples were collected for 12 months from four different sites every fortnight and grouped into four seasons. The sampling sites are either ecologically sensitive or severely affected by contamination. The methylotrophic densities were found high in river Cooum 5.9 to $6.7 \mathrm{Log}$ CFU mL $\mathrm{mL}^{-1}$ than Adyar river 5.5 to $5.9 \mathrm{Log} \mathrm{CFU} \mathrm{mL}^{-1}$ and also fluctuated significantly over time which showed a clear seasonal variation. The bacterial count also varied depending upon the nature of site of sample collection with gradual decrease from upstream to downstream. Cluster analysis (similarity) based on the average values of methylotrophic counts explained the site-wise and monthwise relationship individually.
\end{abstract}

\section{Introduction}

Study of bacterial community is complicated by the dilution, survival and re-suspension of sediment bound groups, which are all affected by continuous and often violent environmental fluctuations (Martinez-Urtaza et al., 2004). Sewer outflows and runoffs from farms and urban areas are reported to carry a wide diversity of microbial communities to the coastal regions through rivers (Pruss, 1998). There are numerous reports on the diversity of different groups of bacteria with different potential traits.
However, diversity and population analysis of methylotrophs are very much limited. These are the bacterial group with the ability to grow at the expense of reduced carbon compounds containing one or more carbon atoms with no carbon-carbon bonds as sole source of energy and have been known since the late 19th century (Patt et al., 1976). They also represent promising organisms in biotechnology for the conversion of onecarbon (C1) substrates to value-added products such as single cell proteins, 
vitamins, aminoacids, biopolymers, enzymes, products of biotransformation and also for their role in carbon-cycling, bioremediation and in replacing petrochemical-based chemical processing in future (Chistoserdova et al., 2003; Schradar et al., 2009).Members of this group possess great metabolic versatility with the ability to scavenge trace amounts of single carbon, nitrogen and resistance to a certain degree of desiccation which contributes their survival in the hostile environments (Anthony and Williams, 2003). Faria and Lokabharathi (2006) reported the marine and estuarine methylotrophs abundance in the samples of Dona Paula beach, Goa, India. Active methylotrophs present in the sediments of Lonar Lake, India, was reported earlier (Antony et al., 2010). There are few reports that depict the diversity of methylotrophs especially in phyllosphere of rice, cotton, maize and sunflower plants (Balachandar et al., 2008; Raja et al., 2008;). However, diversity of methylotrophs in river ecosystems as a whole remains unexplored. Chennai (Madras), the capital of Tamil Nadu state, the fourth largest metropolitan city in India is located on the southeast Coramandel coast of Bay of Bengal is traversed by four waterways namely River Cooum, River Adyar, Buckingham Canal and Otteri Nullah. Of the rivers, the major ones are the River Cooum, runs in the centre of the city and the Adyar River, meandering through the south of Chennai. The waterways of Chennai are not perennial but receive flood discharge and surplus water released from the reservoirs during the monsoon season. These waterways constitute an important environmental component for absorption of wastewater, recharge of groundwater aquifers and also for maintaining the aesthetic quality. Both Cooum and Adyar Rivers are heavily polluted with effluents and waste from domestic and other sources. They serve as elongated lagoons for reception of wastewater from a wide range of domestic, commercial and industrial enterprises. The total drainage area of the waterways basin in Chennai city has been estimated to be 83 $\mathrm{Km}^{2}$. The state government periodically removes silt and pollution from the Adyar River, which is much less polluted than the River Cooum. As a consequence of pollution, these Rivers carry large diverse microbial populations (Shanmugam et al., 2007). Therefore the present study was undertaken for the first time to study the methylotrophic bacterial count from rivers, Cooum and Adyar River (two main water ways) in Chennai, Tamil Nadu, India in response to the seasonal variation.

\section{Materials and Methods}

\section{Site of Sample Collection}

Water samples were collected for 12 months along the Cooum and Adyar Rivers, Chennai.

Cooum River water: The River rises due to the bifurcation of Nallar River at Kesavaram anikat near Arakkonum. From Arakkonam, it takes its own course and passes through the suburbs and small towns in the west of Chennai Tamil Nadu, India. It enters Chennai near Thiruverkkadu and meets sea near marina beach. This carries predominately the seweage generated from the settlements of suburban regions of Chennai. Water samples were collected from 4 sites namely Choolaimedu (MLW), Thousand lights (MQW), Chithadripet (MIW) and Chepauk (MNW).

Adyar River water: The River rises in the Chembarambakkam tank, flows through the city of Chennai, Tamil Nadu, India for a distance of $14 \mathrm{~km}$, before it joins the Bay of Bengal. Urban pollution, mainly contributed 
by waste water disposal within the city limits and industrial effluents enters the Adyar River through several outlets and empties into the Bay of Bengal. Water samples were collected from 4 sites along the river which includes Saidapet (MDW), Kotturpuram (MOW), Adyar (MHW) and Fore shore estate (MFW).

A map showing the sites of sampling spots along Cooum and Adyar Rivers in Chennai and different forests in various districts of Tamil Nadu, India were presented in Pic.1.

\section{Collection of Water Samples}

A total of 96 water samples were collected from the each four sampling sites along Cooum and Adyar Rivers, Chennai, Tamil Nadu, India, every fortnight from June to May. Water samples for microbiological examination were collected using the standard procedure, one meter away from the shore at a depth of a few centimeters using $50 \mathrm{~mL}$ sterile bottles for each sample. Samples were placed in ice and transported to the laboratory and processed on the same day of collection. $\mathrm{pH}$ and temperature of the water samples were recorded at the collection site using a digital $\mathrm{pH}$ meter Eco Scan (Eu-tech instruments, Singapore) and mercury centigrade thermometer.

\section{Preparation of Samples and Culture Conditions}

Enumeration and isolation of methylotrophs were carried out in specific Methanol Mineral Salts (MMS) medium containing $0.5 \%(v / v)$ methanol as carbon source. Water samples were serially diluted upto 5 folds in sterile MMS media and evenly spread plated. The plates were incubated at room temperature $30 \pm 2^{\circ} \mathrm{C}$ upto 15 days. The necessary control plates for MMS medium with and without methanol were maintained.
Following incubation, colony-forming units (CFU) were counted and the results were recorded as Log CFU $\mathrm{mL}^{-1}$.

\section{Statistical Analysis}

Unless otherwise mentioned, all the results were evaluated by analysis of variance (ANOVA) and means were compared by applying Tukey's test using SPSS 14.0 statistical package. The level of statistical significance was accepted as $\mathrm{P}<0.05$.

\section{Results and Discussion}

The study period of enumeration (June to May) was grouped into three seasons viz., June, July, August and September as South West (SW) monsoon, October, November, December and January as North East (NE) monsoon and February, March, April and May as Post monsoon (PM). The average methylotropic counts for different periods such as South West (SW) monsoon, North East (NE) monsoon and Post monsoon (PM) of River Cooum and Adyar of Chennai are depicted in Fig. 1a \& 1b. The methylotrophic population ranged from 5.7 . 6.5 Log CFU $\mathrm{mL}^{-1}$ during the $\mathrm{SW}$ monsoon, 5.5 - 6.1 Log CFU $\mathrm{mL}^{-1}$ during the $\mathrm{NE}$ monsoon and 6.6 - 7.4 Log CFU $\mathrm{mL}^{-1}$ during the PM in Cooum River, Chennai. In Adyar River, the methylotrophs ranged from $5.4-$ 6.1 Log CFU mL $\mathrm{mL}^{-1}, 5.3-5.7 \mathrm{Log}$ CFU $\mathrm{mL}^{-1}$ and 6.0 - 6.3 Log CFU $\mathrm{mL}^{-1}$ during the $\mathrm{SW}$, $\mathrm{NE}$ and PM respectively.

The results revealed that the Cooum River harbored significantly higher number of methylotrophic bacteria ranging from 5.9 to 6.7 Log CFU mL $\mathrm{mL}^{-1}$ than Adyar River with 5.5 to $5.9 \mathrm{Log} \mathrm{CFU} \mathrm{mL}^{-1}$ ( $\mathrm{P}$ value $<0.005$ ) (Fig. 2).Among the four sites along Cooum River, site 1 (Choolaimedu - MLW) had the highest average level of $6.7 \mathrm{Log} \mathrm{CFU} \mathrm{mL} \mathrm{m}^{-1}$ methylotrophs followed by site 2 (Thousand 
lights - MQW) with 6.3 Log CFU mL ${ }^{-1}$, site 3 (Chithadripet - MIW) with 6.1 Log CFU $\mathrm{mL}^{-1}$ and the least level was observed in site 4 (MNW) with 5.9 Log CFU mL $\mathrm{mL}^{-1}$ irrespective of the seasons. In Adyar river, highest count was observed in site 2 (MOW) with $6.2 \mathrm{Log}$ $\mathrm{CFU} \mathrm{mL} \mathrm{mL}^{-1}$ followed by site 1 and 3 (saidapet - MDW with 5.9 and adyar - MHW with 5.7 Log CFU mL $\mathrm{m}^{-1}$ ). The least was found in site 4 (fore shore - MFW) with 5.5 Log CFU $\mathrm{mL}^{-1}$.

Cluster analysis (similarity) was carried out based on the average values of methylotrophic counts to understand the site-wise and month-wise relationship individually. Data grouped according to the sites of the Cooum and Adyar rivers formed three clusters (Fig. 3). Cluster 1 comprised site 1 (Saidapet, MDW) of River Adyar. Site 1 of Cooum (Choolaimedu, MLW) and site 2 of Adyar (Kotturpuram, MOW) Rivers formed cluster 2. Cluster 3 was formed by sites 3 and 4 of both the river (Chithadripet, MIW; Chepauk, MNW; Adyar, MHW; Fore shore estate, MFW).

The dendrogram for similarity of monthwise methylotrophic counts of Cooum river showed three clusters (Fig. 4). Cluster 1 was formed by the month May. Months of South west monsoon and North East monsoon occupied second cluster. Months namely February, March and April formed cluster 3. Clustering of methylotrophic counts in Adyar River generated a dendrogram, grouping the 12 months into two clusters (Fig. 5). Cluster 1 was further divided into two clusters: South west monsoon (June September) and North East monsoon (October - January). Cluster 2 consisted of months February - March also includes the month of May.

The analytical data of the river water such as $\mathrm{pH}$ and temperature are summarized in Table 1. The $\mathrm{pH}$ values throughout the study ranged from 6.0 to 7.8 and 6.0 to 8.8 in the sites of Cooum and Adyar Rivers. The $\mathrm{pH}$ was high during post monsoon period which ranged from 6.5 to 9.0 in Cooum and 7.0 to 8.8 in Adyar Rivers. During SW and NE monsoon period, the water samples of Cooum River had $\mathrm{pH}$ ranged from 6.0 to 7.5. The $\mathrm{pH}$ of Adyar River ranged from 6.0 to 7.8 during $\mathrm{SW}$ and NE monsoon period. During the study period, the water temperature ranged from $20^{\circ} \mathrm{C}$ to $35^{\circ} \mathrm{C}$ in Cooum and Adyar rivers with maximum in post monsoon period $\left(30^{\circ} \mathrm{C}\right.$ to $\left.35^{\circ} \mathrm{C}\right)$ and minimum in $\mathrm{SW}$ and $\mathrm{NE}$ monsoon period $\left(20^{\circ} \mathrm{C}\right.$ to $\left.28^{\circ} \mathrm{C}\right)$.

The rivers carried higher methylotrophic count during post monsoon and lower numbers during the SW and NE monsoon. Anand et al. (2006a) reported higher bacterial count (total bacterial count) in dry seasons and the lowest in rainy months in the water samples of River Yamuna in Delhi. The results of the present study suggest the trend of Neumann et al. (1972) who reported that in the tropical countries the seasonal cycle of the micro organism can be correlated with the lowest numbers in rainy months, and the highest numbers in dry season.

Similarly Sood et al (2008) reported higher total viable count in summer than rainy season from the water samples of Gangetic river system of Uttarakhand (India). However, the reason for this could be due to the reduced flow of water content in the river during post monsoon months (March, April, May and June) which would have supported the bacterial survival when compared to other seasons (Anand et al., 2006b). From this study, it is also evident that the significant reduction of bacterial count in River Cooum and Adyar during NE monsoon may be due to the flushing effect of rain, while comparatively high count during the SW monsoon months may be due to receiving of surface runoffs. 
The River Cooum harbored significantly higher methylotophic population than the Adyar River. In general it has been found that the waters of the Cooum River are grossly contaminated by microbial flora, than the Adyar River which could be related to the impact of human activities including land drainage, dumping of enormous quantities of sewage, discharge of untreated municipal wastewater and industrial effluents and natural changes (Ezeronye and Ubalua, 2005). Moreover, the state government periodically removes silt and pollution from the Adyar River, which is much less polluted than the River Coovum (Shanmugam et al., 2006). The population of resident bacteria in the river basins also differs greatly with respect to the degree of the impact of human activities on them. The variation in the count depending upon the nature of site of sample collection with gradual decrease from upstream to downstream can be discussed with the increased anthropogenic activities and social-cultural activities at different sites of river stretches as reported by Kumarasamy et al. (2009).

Cluster analysis is a helpful tool for organizing a particular set of data from various points into clusters or groups and determining the relationship between the various points (McGarial et al., 2000). Hence the sampling sites in both the rivers and the sampling months were grouped in accordance with the methylotrophic count using cluster analysis. Clustering of sampling sites formed four clusters, the upstream site (MDW) of Adyar river formed cluster I as it has relatively lesser methylotrophic count than other sites. The most probable explation could be that the saidapet (MDW) site of Adyar River was widely used for the laundry purposes and readily contaminated with detergents which might have inhibited the growth and could be responsible for the decreased count. Venugopal et al. (2008) reported the effect of laudering in the quality of Adyar river water. Further, the effect of detergents over the microflora in the River Nile water was well defined by Issa and Ismail (1994). In support, Salton (1953) has reported that a Gram-negative bacterium that contains appreciable amounts of lipid gets disaggregated due to the exposure of detergents. Sampling site MLW (Cooum River) at the upstream end formed second cluster and this site was observed with relatively higher methylotrophic count during the study period. The reason may be due to the prevailed highest domestic human activities in the stretch of the river around this site including the discharge of domestic waste, sewage outfalls and absence of sanitation facilities. Irrespective of the rivers, sites MQW (Cooum River), MIW Cooum River), MOW (Adyar River) and MHW (Adyar River) at the intermediate regions of the river stretch were grouped together as cluster III while the sites MNW (Cooum River) and MFW (Adyar River) at the downstream stretch were found closer to form cluster IV. The results of the cluster analysis suggested that the variation in the total count of methylotrophs in the sampling sites might also be dependent on the order of magnitude, greater at the freshward than at the seaward end, which could be attributed to the tidal movements and dilution of bacterial count due to variations in the continual confluence of freshwater and coastal water at the downstream (Neill, 2004). According to Neal (1972), the bacteria entering the estuary from the river and the coastal ocean are mixed by tidal actions which were then washed out of the estuary by incoming coastal marine water. Moreover it has been reported that the bacterial population in a river depends on the function of initial loading and the disappearance rate, which, in turn, is a 
function of the time or the distance of travel from the source and of other factors including temperature, salinity, and light intensity (Eleria and Vogel, 2005). These factors might have contributed, independently or in combination, to the levels of methylotrophic bacterial counts that were observed at these sampling sites of the two rivers.

Fig.1a Seasonal Variations of Methylotrophic Bacterial Counts in Cooum River

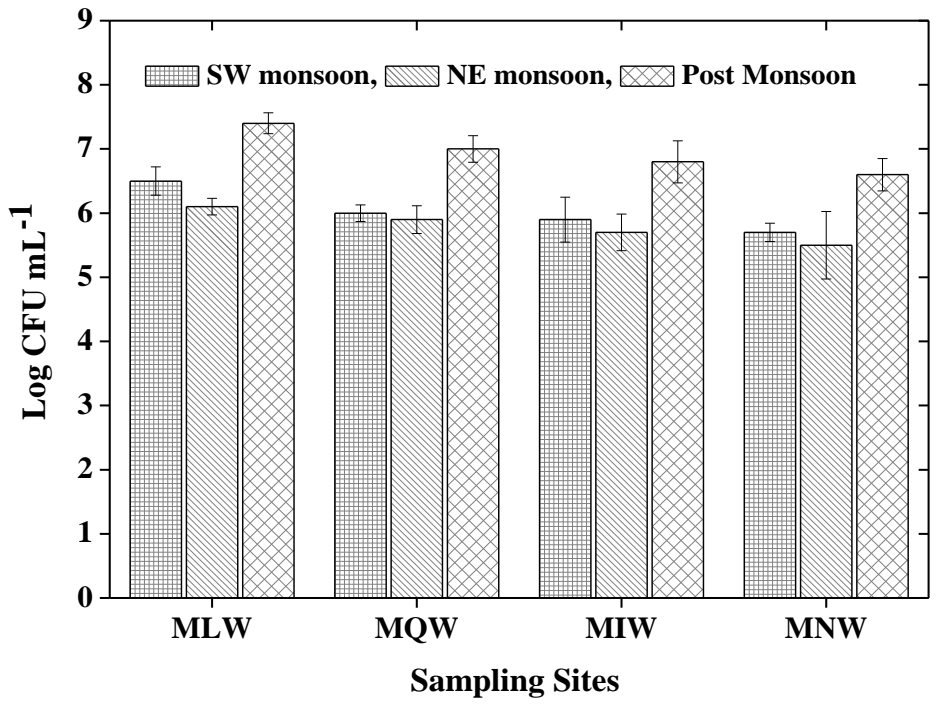

Fig.1b Seasonal Variations of Methylotrophic Bacterial Count in Adyar River

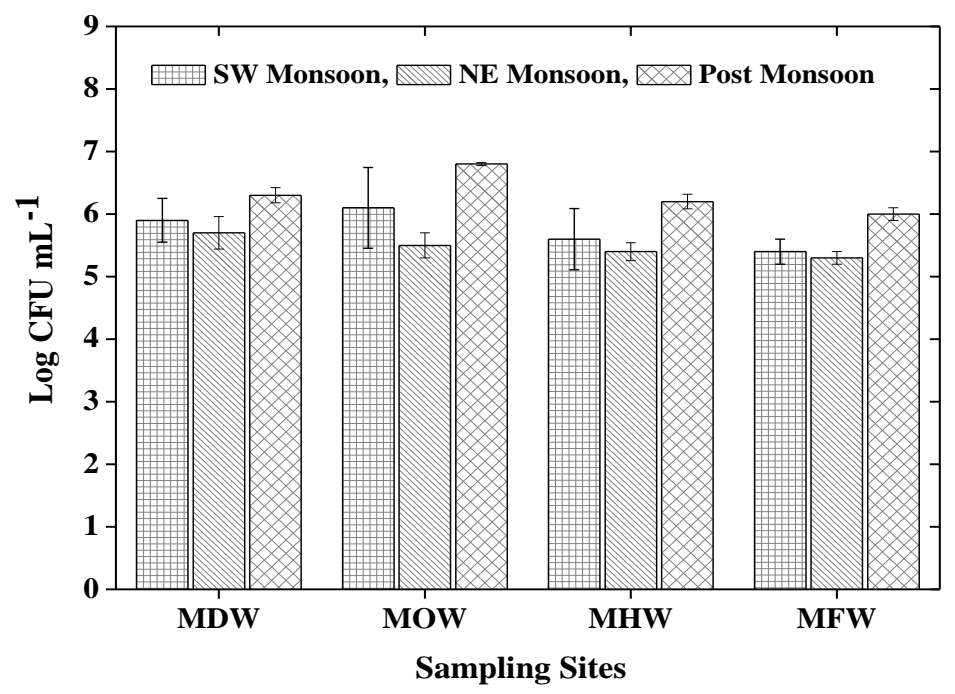

SW - South West monsoon (June, July, August and September ); NE - North East monsoon (October, November, December and January); Post monsoon (February, March, April and May)

Water samples collected every month for 12 months were serially diluted and plated on MMS medium containing $0.5 \%$ methanol as carbon source and incubated at room temperature $30 \pm 2{ }^{\circ} \mathrm{C}$.

Values represent the mean \pm S.D. of four determinations. 
Fig.2 Overall Methylotrophic Bacterial Counts in the Sampling Sites of Cooum River and Adyar River

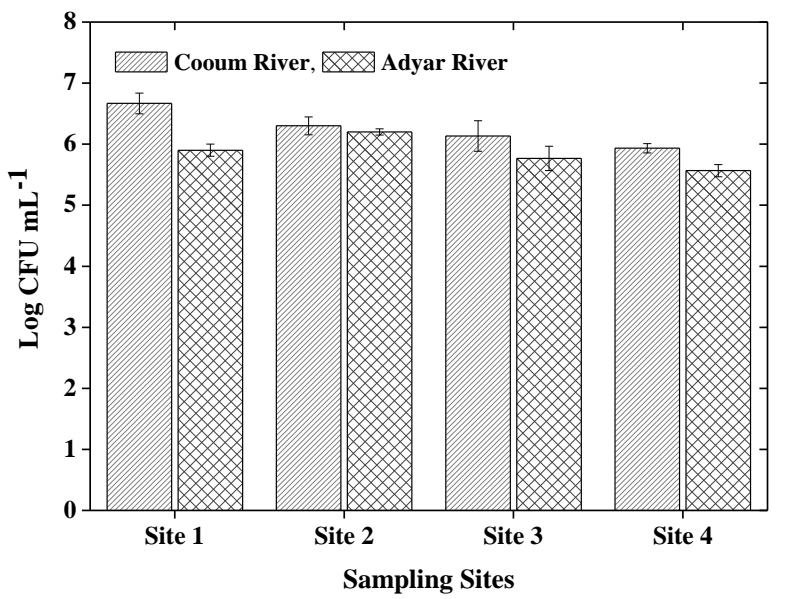

Cooum River: Site 1 - Choolaimedu (MLW); Site 2 - Thousand lights (MQW); Site 3 - Chithadripet (MIW); Site 4 Chepauk (MNW)

Adyar River: Site 1 - Saidapet (MDW); Site 2 - Kotturpuram (MOW); Site 3 - Adyar (MHW); Site 4 - Fore shore estate (MFW)

Results represent mean \pm SD.

Fig.3 Dendogram Showing the Relationship of Methylotrophic Counts among the Sampling Sites of Cooum River and Adyar River

Dendrogram using Average Linkage (Between Groups)

Rescaled Distance Cluster Combine

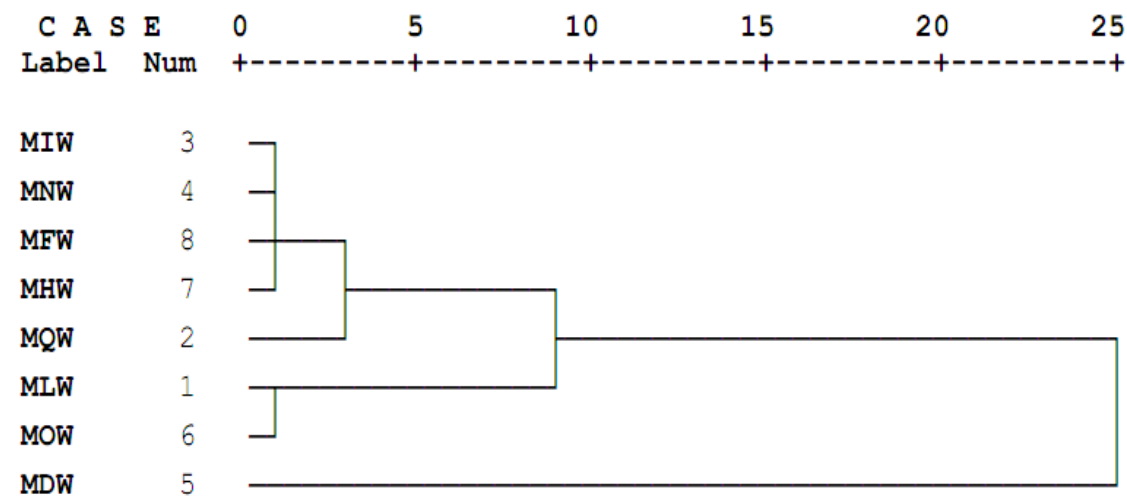

Cooum River: Site 1 - Choolaimedu (MLW); Site 2 - Thousand lights (MQW); Site 3 - Chithadripet (MIW); Site 4 Chepauk (MNW)

Adyar River: Site 1 - Saidapet (MDW); Site 2 - Kotturpuram (MOW); Site 3 - Adyar (MHW); Site 4 - Fore shore estate (MFW)

Clusters formed between the sampling sites of the Cooum and Adyar Rivers of Chennai based on the methylotrophic counts in the water samples to understand the relationship among the stations.

Dendrogram was derived from Pearson correlation. 
Fig.4 Dendogram Showing the Relationship among the Months in Methylotrophic Counts of Cooum River

Dendrogram using Average Linkage (Between Groups)

Rescaled Distance Cluster Combine

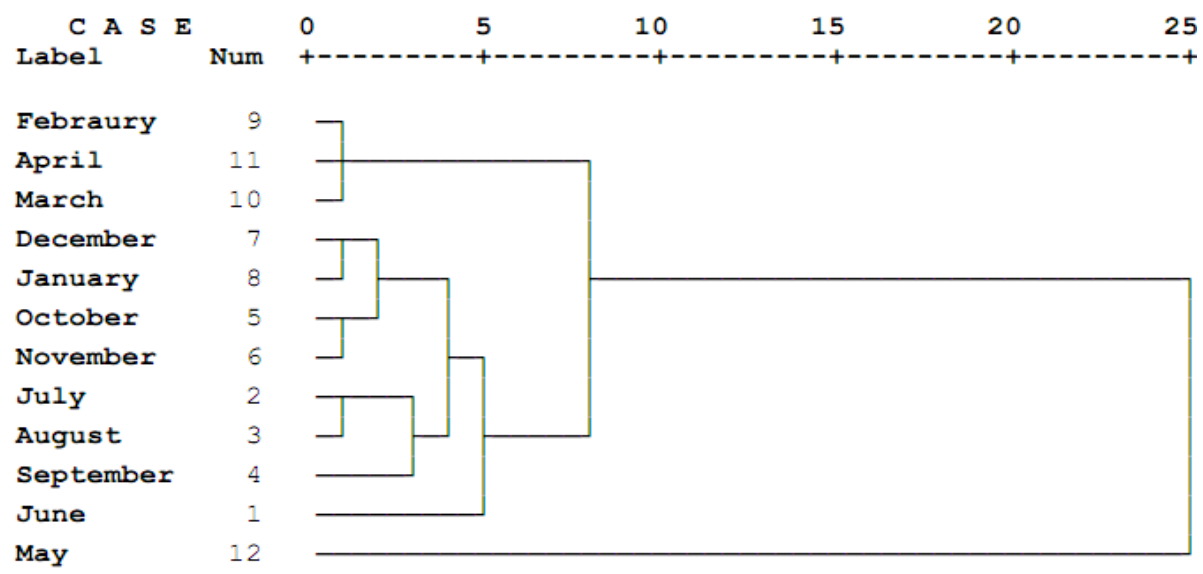

Clusters based on the methylotrophic counts collected between the months in the water samples collected from Cooum River of Chennai.

SW - South West monsoon (June - September); NE - North East monsoon (October - January); Post monsoon (February - May).

Dendrogram was derived from Pearson correlation.

Fig.5 Dendogram Showing the Relationship among the Months in Methylotrophic Counts of Adyar River

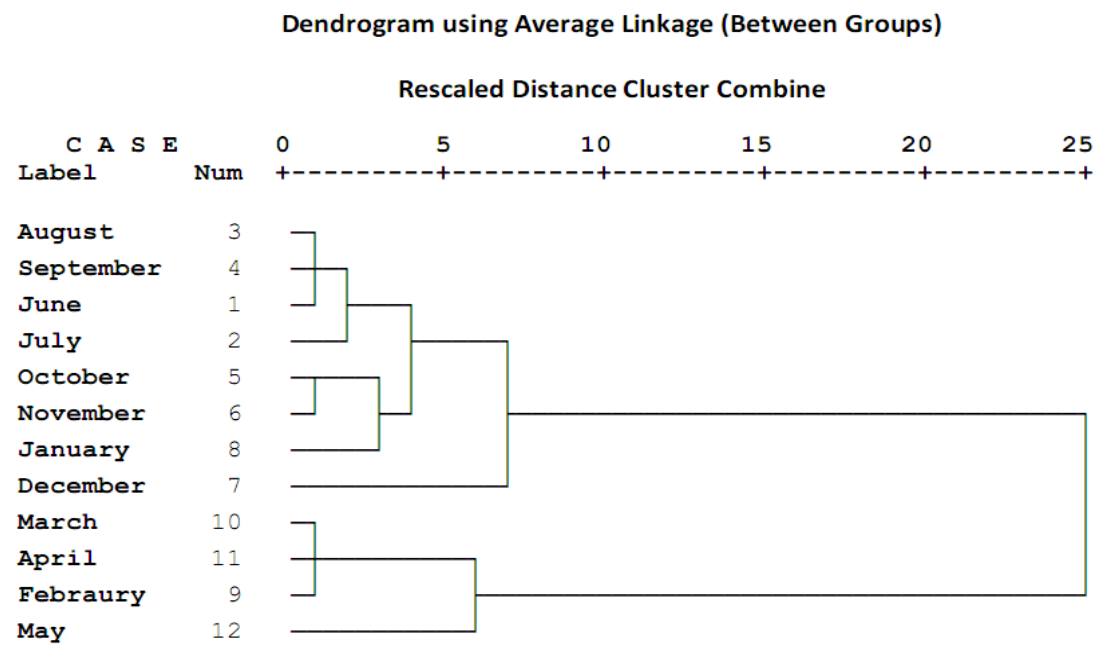

Clusters based on the methylotrophic counts collected between the months in the water samples collected from Adyar River of Chennai.

SW - South West monsoon (June - September); NE - North East monsoon (October - January); Post monsoon (February - May).

Dendrogram was derived from Pearson correlation. 
Pic.1 Map Showing the Sites of Sampling Spots Along Cooum and Adyar Rivers in Chennai, Tamil Nadu, India

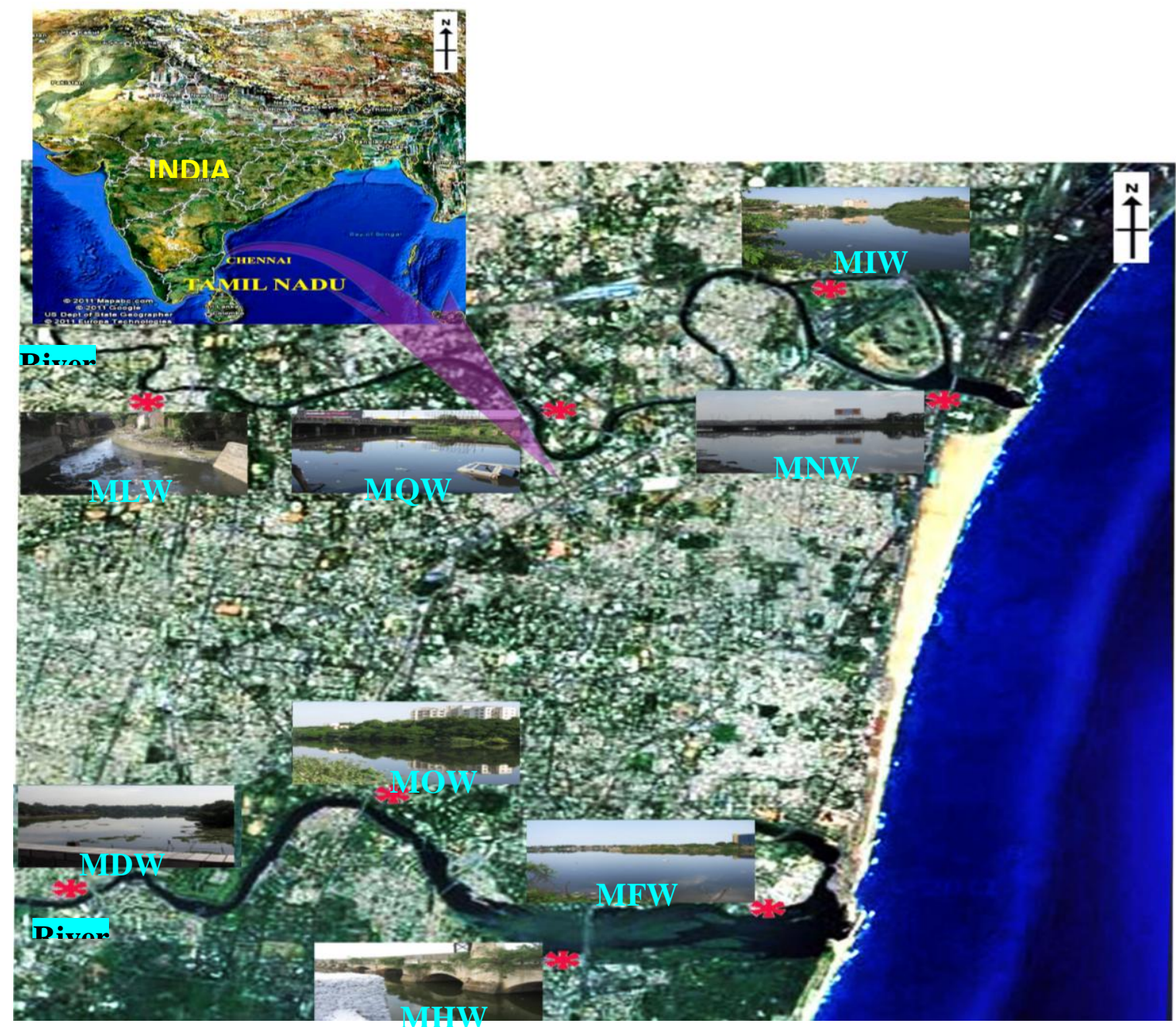

* Stars represent the sites of sample collection.

Water samples were collected from each four sites along Cooum and Adyar Rivers, Chennai every fortnight for 12 months and were enumerated for methylotrophic count by serial dilution method.

Clustering of methylotrophic count based on sampling months showed the seasonal effect on the methylotrophs population. In both the rivers, irrespective of their nature, the months were grouped as two main clusters except in Cooum River where the count in the month of May 08' formed a separate cluster which may be due to transition period of methylotrophic count from one season to another. Post monsoon have formed the Cluster I, which could be characterized as the effect of reduced water flow in the river due to absence of rainfall. It has also been reported that these rivers serves as a conveyor of storm water from the city's sewage drain network which becomes stagant during post monsoon with rich organic matter (Shanmugam et al., 2006). In contrast, the methylotrophic population during the SW monsoon (June, July, August and September) and NE monsoon (October, November, December and January) formed the $2^{\text {nd }}$ cluster indicating the effect of influence of rain which tend to push the 
river waters toward seaward direction and also the soil runoffs during this season. In both the rivers Cluster I recorded the maximum methylotrophic population when compared to cluster II. This shift in bacterial count from cluster I to another may be due to the effect of monsoon. Castillo (2000) has reported the influence on hydrologic seasonality in rivers of differing chemistry which varied across years of contrasting rainfall patterns. Besides, influence of key factors such as light, salinity, rainfall, available nutrients and environmental pollutants on the bacterial growth and abundance in water bodies has also been reported earlier (Pernthaler et al., 1998; Solo-Gabriele et al., 2000; Bezuidenhout et $a l ., 2002)$. This indicated that the population of methylotrophs over a point of 1 year resembles two periods in water samples of River Cooum and Adyar.

The $\mathrm{pH}$ of river water in all the stations was found to be slightly acidic during monsoon period but changed to slight alkaline condition during post monsoon. The observed variation in $\mathrm{pH}$ could be attributed to the negligible terrestrial runoff, precipitation and also absence of fresh water discharge caused the change of $\mathrm{pH}$ within a very narrow limit. The surface water temperature during the present study varied with current reversal. Similar variation of temperature has been reported earlier (Venugopal et al., 2008). However, in the water samples methylotrophic density does not seem to be correlated with temperature. This finding suggests that temperature is not the only factor driving differences in seasonal variation in bacterial count but also fluctuations in other factors such as substrate and nutrient availability (Castillo et al., 2004).

The results indicate that Cooum and Adyar Rivers in Chennai are rich source of methylotrophic bacteria which in turn could be a source of various compounds. Further studies on these sites including study of various microbial biodiversity and evaluation of biotechnological potential of the isolated strains with exploration of functional aspects would add value for their use in large scale application.

\section{Acknowledgment}

The authors thank Life Sciences Research Board, DRDO, India, and Department of Biotechnology, Government of India for financial support and Shri AMM Murugappa Chettiar Research Center for providing necessary facilities.

\section{References}

Anand, C., Akolkar, P., Chakrabarti, R. 2006a. Bacteriological water quality status of river Yamuna in Delhi. J. Environ. Biol., 27: 97-107.

Anand, P.T., Bhat W.A., Shouche, S.Y., Roy, U., Siddharth, J., Sarma, P.S. 2006b. Antimicrobial activity of marine bacteria associated with sponges from the waters off the coast of South East India. Microbiol. Res., 161(3): 252-262.

Anthony, C., Williams, P. 2003. Review: The structure and mechanism of methanol dehydrogenase. Biochim. Biophys. Acta., 1647: 18-23.

Antony, P.C., Kumaresan, D., Ferrando, L., Boden, R., Moussard, H., Scavino, F.A., Shouche, S.Y., Murrell, C.J. 2010. Active methylotrophs in the sediments of Lonar Lake, a saline and alkaline ecosystem formed by meteor impact. J. Int. Soc. Microb. Ecol., 4: 1470-1480.

Balachandar, D., Raja, R., Sundaram, S.P. 2008. Genetic and metabolic diversity of pink-pigmented facultative 
methylotrophs of tropical plants. Braz. J. Microbiol., 39: 68-73.

Bezuidenhout, C.C., Mthembu, N., Puckree, T., J Lin, J. 2002. Microbiological evaluation of the Mhlathuze River, KwaZulu-Natal (RSA).Water SA., 28(3): 281-286.

Castillo, M.M. 2000 Influence of hydrological seasonality on bacterioplankton in two neotropical flood plain lakes. Hydrobiologia, 437: $57-65$.

Castillo, M.M., Allan, D.J., Sinsabaugh, R., Kling, W.G. 2004. Seasonal and interannual variation of bacterial production in lowland rivers of the Orinoco basin. Freshwater Biol., 49: 1400-1414.

Chistoserdova, L., Chen, S.W., Lapidus, A., Lidstrom, M.E. 2003. Methylotrophy in Methylobacterium extorquens AM1 from a Genomic Point of View. $J$. Bacteriol., 185(10): 2980-2987.

Eleria, A., Vogel, R.W. 2005. Predicting Fecal Coliform bacteria levels in the Charles River, Massachusetts, USA. J. Amer. Water Res. Assoc., 41(5): 1195-1209.

Ezeronye, O.U., Ubalua, A.O. 2005. Studies in the effect of abattoir and industrial effluents on the heavy metals and microbial quality of Aba River in Nigeria. Afri. J. Biotechnol., 4(3): 266-272.

Faria, D., Lokabharathi, P.A. 2006. Marine and estuarine methylotrophs: Their abundance, activity and identity. Curr. Sci., 90(7): 984-989.

Issa, A.A., Ismail, M.A. 1994. Effects of detergents on River Nile water microflora. J. Islamic Aca. Sci., 7(3): 157-162.

Kumarasamy, P., Vignesh, S., James, R.A., Muthukumar, K., Rajendran, A. 2009. Enumeration and identification of pathogenic pollution indicators in
Cauvery River, South India. Res. J. Microbiol., 4(12): 540-549.

Martinez-Urtaza1,J., Saco, M., de Novoa, J., Perez-Piñeiro,P., Peiteado, J.,Lozano-Leon, A., Garcia-Martin, O. 2004. Influence of Environmental Factors and Human Activity on the Presence of Salmonella Serovars in a Marine Environment. Appl. Environ. Microbiol., 70(4): 2089-2097.

Mcgarial, K., Cushman, S., Stafford, S. 2000. Multivariate statistics for wildlife \& ecology research. Springer. Berlin Heidelberg and New York.

Neal, V.T. 1972. Physical aspects of the Columbia River and its estuary. In: Pruter, A.T., Alverson, D.L. (ed.). The Columbia River estuary and adjacent ocean waters. University of Washington Press. Seattle. USA.

Neill, M. 2004. Microbiological Indices for total coliform and $E$. coli bacteria in estuarine waters. Mar. Pollut. Bull., 49(9-10): 752-760.

Neumann, D.A., Benenson, M.W., Hubster, E., Tuan, N.T., Tien-Van L. 1972. Vibrio parahaemolyticus in the Republic of Vietnam. Am. J. Trop. Med. Hyg., 21(4): 464-466.

Patt, E.T., Cole, G.C., Hanson, D.R.S. 1976. Methyloobacterium, a new genus of facultatively methylotrophic bacteria. Int. J. Sys. Bacteriol., 26(2): 22-229.

Pernthaler, J., Glöckner, F-O., Unterholzner, S., Alfreider, A., Psenner, R., Amann, R. 1998. Seasonal community and population dynamics of pelagic bacteria and archaea in a high mountain lake. Appl. Environ. Microbiol., 64 (11): 4299-4306.

Pruss, A. 1998. A review of epidemiological studies from exposure to recreational water. Int. J. Epi., 27: 1-9.

Raja, P., Balachandar, D., Sundaram S.P. 2008. Genetic diversity and phylogeny of pink-pigmented 
facultative methylotrophic bacteria isolated from the phyllosphere of tropical crop plants. Biol. Fert. Soils, 45(1): 45-53.

Salton, M.R.J. 1953. The composition of the cell walls of some Gram-positive and Gram-negative bacteria. Biochim. Whys. Acta., 10: 512-523.

Schrader, J., Schilling, M., Holtmann, D., Sell, D., Filho, M.V., Marx, A., Vorholt, J.A. 2009. Methanol-based industrial biotechnology: current status and future perspectives of methylotrophic bacteria. Trends Biotechnol., 27: 107-115.

Shanmugam, P., Neelamani, S., Ahn, Y.H., Philip, L., Hong, G.H. 2006. Assessment of the levels of coastal marine pollution of Chennai city, Southern India. Water Res. Manage., 21: 1187-1206.
Solo-Gabriele, H.M., Wolfert, M.A., Desmarais, T.R., Palmer, C.J. 2000. Sources of Escherichia coli in a coastal subtropical environment. Appl. Environ. Microbiol., 6(1): 230-237.

Sood, A., Singh, K.D., Pandey, P., Sharma, S. 2008. Assessment of bacterial indicators and physicochemiocal parameters to investigate pollution status of Gangetic river system of Uttarakhand (India). Ecol. Indic., 8(5): 709-17.

Venugopal, T., Giridharan, L., Jayaprakash, M. 2008. Groundwater quality assessment using chemometric analysis in the Adyar River, South India. Arch Environ Contam Toxicol. 55(2): 180-190.

\section{How to cite this article:}

Jayashree Shanmugam, Vadivukkarasi Ponnusamy, Mayakkannan Gopal and Sundaram Seshadri. 2016. Population Dynamics and Seasonal Variation of Bacterial System Utilizing Single Carbon from River Cooum and River Adyar, Chennai, Tamilnadu, India. Int.J.Curr.Microbiol.App.Sci. 5(3): 466-477. doi: http://dx.doi.org/10.20546/ijcmas.2016.503.055 